\title{
イヌ健常歯肉における歯肉溝滲出液中のコンドロイチン 硫酸プロテオグリカンの由来
}

\author{
柴 田麻 紀 村橋 慶宣塚田 英治 \\ 堀木到岩山幸 雄 \\ 朝日大学歯学部歯周病学講座 \\ (主任：岩山幸雄) \\ (平成 6 年 3 月 18 日受付)
}

\section{The Origin of Chondroitin Sulfate Proteoglycans in Gingival Crevicular Fluid of Dogs with Healthy Gingiva \\ Maki SHIBATA, Yoshinobu MURAHASHI, Eiji TSUKADA, Itaru HORIKI and Yukio IWAYAMA \\ Department of Periodontology, Asahi University, School of Dentistry 1851-1, Hozumi, Hozumi-cyo, Motosu-gun, Gifu 501-02, Japan}

(Chief : Prof. Yukio IWAYAMA)

The purpose of this study was to investigate the origin of chondroitin sulfate proteoglycans (chondroitin 4 sulfate proteoglycan, C $4 \mathrm{~S}-\mathrm{PG}$, chondroitin 6 sulfate proteoglycan, C $6 \mathrm{~S}-\mathrm{PG}$ ) in the gingival crevicular fluid (GCF) of dogs with healthy periodontal tissues.

Chondroitin sulfate proteoglycans obtained from gingiva, serum and GCF were separated by SDS -PAGE, blotted onto nitrocellulose membranes by Western blotting technique, and immunostained with specific antibodies (3-B-3, 2-B-6) against chondroitin sulfate proteoglycan isomers.
The major bands of C $4 \mathrm{~S}-\mathrm{PG}$ in GCF samples yielded an electrophoretic profile similar to that of serum. However, the GCF samples showed a few minor migrating bands which were not detectable on serum samples, coincident in electrophoretic mobility to those of gingival samples.

The distribution profile of $\mathrm{C} 6 \mathrm{~S}-\mathrm{PG}$ on electrophoresis was similar to that of $\mathrm{C} 4 \mathrm{~S}-\mathrm{PG}$ in all samples.

These observations show that chondroitin sulfate proteoglycans detected in GCF samples could be derived partly from gingiva as well as serum.

Key words : Proteoglycan, Gingival crevicular fluid, Western blotting

要旨: 本研究はイヌの歯肉溝滲出液 $(\mathrm{GCF})$ 中のコンドロイチン硫酸プロテオグリカン（コンドロイチン 4 硫 酸プロテオグリカン C 4 S-PG，コンドロイチン 6 硫酸プロテオグリカンC 6 S-PG）の由来を検討する目的で 行った。

健常歯周組織を確立したイヌの歯肉, GCF, 血清を採取後, コンドロイチン硫酸プロテオグリカン (CS-PG) サンプルを作製した。サンプルは SDS ポリアクリルアミド電気泳動（SDS-PAGE）を行いニトロセルロース膜 に Western blotting した。転写後の膜は CS-PG 異性体に対するモノクローナル抗体（3-B-3，2-B-6）を用い C 4 S-PG と C 6 S-PG の免疫染色を行った。GCF の C 4 S-PG の主要バンドは泳動パターンは血清のものと類似 
していた。しかし，血清には検出されないが，歯肉と合致した位置に数本のバンドを認めた。C $6 \mathrm{~S}-\mathrm{PG}$ の泳動パ ターンは C 4 S-PG と類似していた。以上の結果，GCF の C 4 S-PG，C 6 S-PG の一部は血清と同様，歯肉由来 であることが示された。

索引用語：プロテオグリカン, 歯肉溝滲出液, ウェスタンブロッテング

\section{緒 言}

細胞外マトリックスを構成する基質成分であるグリ コサミノグリカン $(\mathrm{GAG})$ は，組織中では蛋白との 複合体であるプロテオグリカン (PG) として存在し， 結合組織の恒常性維持や, 細胞活動の支配などの重要 な役割を果たしている ${ }^{1 \sim 4)}$ 。

グリコサミノグリカンプロテオグリカン $(\mathrm{GAG}$ -PG）の 1 つであるコンドロイチン硫酸プロテオグリ カン (CS-PG) には構成部分として N-アセチルガラ クトサミン-4 硫酸を持つコンドロイチン 4 硫酸 (C 4 $\mathrm{S}-\mathrm{PG}$ ) と N-アセチルガラクトサミン-6 硫酸を持つ コンドロイチン 6 硫酸 (C 6 S-PG) の異性体が存在 する5)。

歯肉においても生化学的，免疫組織化学的手法を用 いて CS-PG が存在する事が報告されている。一般的 に, 生化学的手法に基ずいた研究では C 4 S-PG のみ が検出されているが, 免疫組織学的手法を用いた最近 の研究においては C 4 S-PG と C 6 S-PG の両者が歯 肉に存在するとされている。

Shibutani ら ${ }^{6}$ はイヌの実験的歯周炎において歯肉 溝滲出液 $(\mathrm{GCF})$ 中の C $4 \mathrm{~S}-\mathrm{PG}$ お よび C $6 \mathrm{~S}-\mathrm{PG}$ を ELISA 法を用いて検索し，急性炎症初期の結禁 3 日 目に C 4 S-PG が，急性炎症の著明な結禁 7 日目に C 6 S-PG がピークに示すことから，これらの CS-PG が炎症による組織破壊の活性を示すマーカーと成りう る可能性を示唆した。また, GCF の C 4 S-PG と C 6 S-PG の比は血清のものよりは歯肉の CS-PG に近い と報告している。

本研究は GCF 中に歯肉代謝産物に由来する C $4 \mathrm{~S}$ -PG，C 6 S-PG が存在するかどうかを検索するため に血清, 歯肉, GCF 中の CS-PG を分子量レベルで 比較検討した。

\section{材料と方法}

\section{1. 材料と方法}

実験動物には雑種成犬 3 頭を用い 1 力月間, 週 2 回
のスケーリングとブラッシングを行い健常歯肉を確立 後, GCF, 歯肉, 及び血清を採取した。GCF は下顎 左右第 3 , 第 4 小臼歯及び第 1 大臼歯部を採取部位と した。歯肉縁上プラークを可及的に除去し水洗乾燥 後, Micro Capillary Tube (MICROCAPS ${ }^{\circledR}$ Drummond USA）を出血させないように歯肉溝内に挿入 して $1 \mu l$ 採取後, ただちに $0.15 \mathrm{M}$ pH 7.2 phosphate buffer saline (PBS) で50 倍希釈し, これを GCF サンプルとした。歯肉は GCF 採取と同部位から 全身麻酔下で採取した。歯肉はホモジナイズし, メ夕 ノールクロロホルムで 30 分間脱脂後, $10,000 \mathrm{G} 15$ 分 間遠心を行った。引き続き湿重量の 50 倍量の $4 \mathrm{M}$ 塩 酸グアニジン含有 $50 \mathrm{mM}$ トリスー塩酸緩衝液 $(\mathrm{pH}$ 7.0）で 24 時間インキュベートして，再度 $10,000 \mathrm{G}$ 15 分間遠心後, 上清のみを採取した。上清は限外濾 過を行って約 5 倍量に濃縮後, 24 時間透析して歯肉 サンプルとした。またイヌの上腕静脈より採血後, 血 清を分離し PBS で 50 倍希釈して血清サンプルとし た。なお全ての操作は $4^{\circ} \mathrm{C}$ の条件下で行い，各サンプ ルはー $80^{\circ} \mathrm{C}$ で保存した。なお試料調整は protease inhibitor (pepstatin phenylme thylsulfonyl fluoride $\mathrm{N}$ -Ethylmaleimide, EDTA) の存在下で行った

\section{SDS-ポリアクリルアミド電気泳動（SDS -PAGE)}

泳動は，FUNA ${ }^{\circledR}$ 電気泳動槽 MODEL-88（FUNAKOSHI）を使用して Laemmli のバッファーシステム に準じて行った。各サンプルと分子量マーカー (Vector Laboratories USA) はサンプルバッファー で希釈調整後, $95^{\circ} \mathrm{C}, 5$ 分間加温してタンパクを変性 させた ${ }^{8)}$ 。ゲルは 4-20\% SDS-PAGE mini gradient

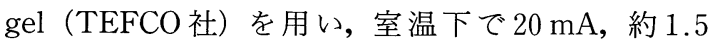
時間の通電で bromophenol blue がゲルの底部に到達 するまで行った。

\section{3. イムノブロットと膜染色}

ゲルから，二トロセルロース膜 (Trans Blot ${ }^{\circledR}$ Transfer Medium, Bio-Rad 社) への転写は FUNA ${ }^{\circledR}$ BLOTTING SET (FUNAKOSHI) を用い, 祖父 江 ${ }^{7,9)}$ ら方法に準じて $4^{\circ} \mathrm{C} 45 \mathrm{~mA}, 20$ 時間の条件下 で行った。転写後の膜はそれぞれ免疫染色した。本実 

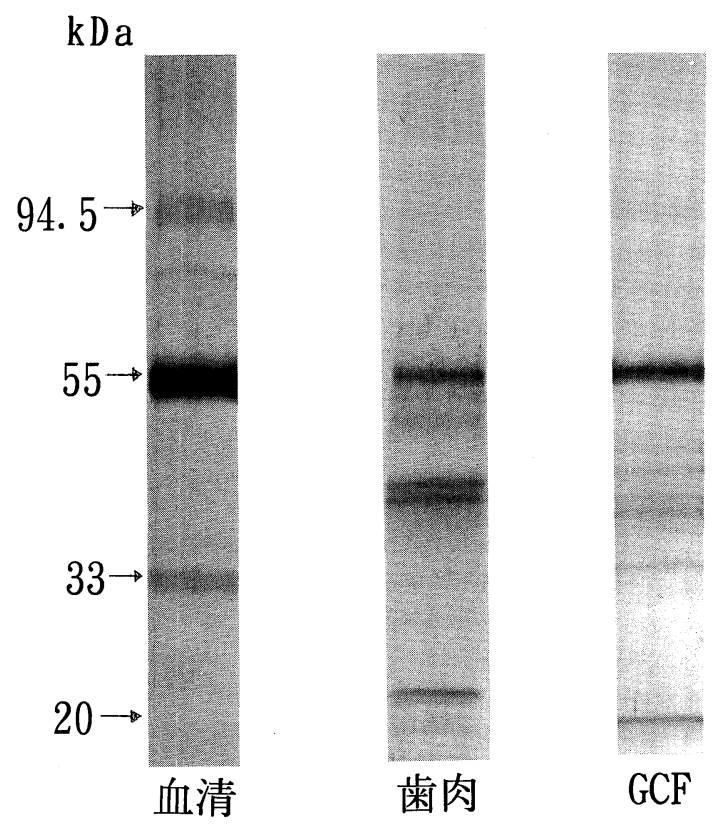

図 1 血清・歯肉・ GCF の C $4 \mathrm{~S}-\mathrm{PG}$ に対する ウエスタンブロッティング

験に用いたモノクローナル抗体は，3-B-3，2-B-6抗 体（生化学工業社 東京）である。これら抗体はCS -PG の糖鎖を酵素により分解したときに生ずるコア 一蛋白断端の不飽和 2 糖をエピトープとして認識する とされている。まず Chondroitinase AC II で消化後 2-B-6 抗体を反応させる事で C 4 S-PG を, Chondroitinase ABC で消化後 3-B-3 抗体を反応させる事 でC 6 S-PG を検出した。すなわち転写後の膜は, Chondroitinase ABC, Protease freeまたはProtease inhibitor を加えたChondroitinase AC II で室 温 3 時間反応後, Tween-20 を含む PBS (PBS-T) で洗浄し，1\%ウシ血清アルブミン（BSA）含有 $\mathrm{PBS}$ で $37^{\circ} \mathrm{C} 2$ 時間ブロッキングした。引き続き 50 倍希釈した 1 次抗体を $4^{\circ} \mathrm{C} 24$ 時間反応させ, PBS-T で洗浄，ビオチンーストレプトアビジンシステム（ニ チレイ）によりラベリングした。すなわち，ビオチン 標識ウサギ抗マウス $\operatorname{IgG}+\operatorname{Ig} A+\operatorname{Ig} M$ を反応させ PBS-T で洗浄後, 続いてペルオキシターゼ標識スト レプアビジンを反応させ， 3,3 diamino-benzidine 4 HCL（DAB）を用い発色させた。その後, 膜は流水 下で洗浄後乾燥し, 各サンプルのバンドを比較検討し た。

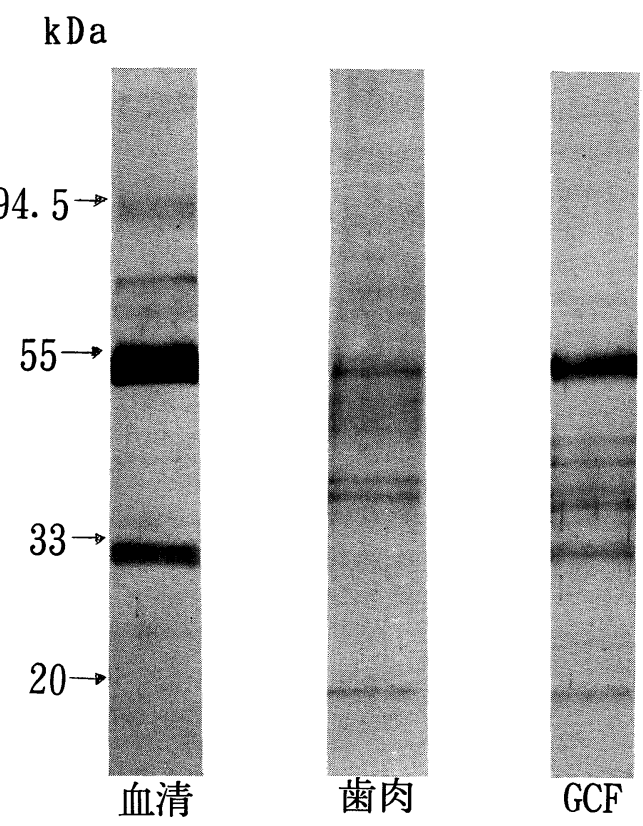

図 2 血清・歯肉・GCF の C 6 S-PG に対する ウエスタンブロッティング

\section{結 果}

本実験に用いた実験動物は 3 頭であるが実験結果に 個体差は認めなかった。

血清の C $4 \mathrm{~S}-\mathrm{PG}$ は $33 \mathrm{kDa}$ と $55 \mathrm{kDa}, 94.5 \mathrm{kDa}$

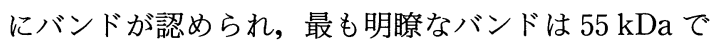
あった。歯肉の C $4 \mathrm{~S}-\mathrm{PG}$ は， $55 \mathrm{kDa} ， 45 \mathrm{kDa} ， 44$ $\mathrm{kDa}$ と $20 \mathrm{kDa}$ 付近に 3 本のバンドを認めた（図 1 )。 歯肉に認められた $55 \mathrm{kDa}$ のバンドは血清のそれに一 致したが， $55 \mathrm{kDa}$ 以外の血清と歯肉のバンドは分子 量が一致しなかった。また血清に存在した $94.5 \mathrm{kDa}$ のバンドは歯肉に検知されなかった。

一方, GCF の C 4 S-PG は $55 \mathrm{kDa}, 33-55 \mathrm{kDa}$ の 範囲に 5-6 本と $20 \mathrm{kDa}$ にバンドを認めた。最も明瞭 なバンドは $55 \mathrm{kDa}$ であった（図 1)。55 kDa のバン ドは血清, 歯肉, GCFに共通していた。GCFの 33-55 kDa 間のバンドの一部と $20 \mathrm{kDa}$ のバンドは血 清には存在しないが，歯肉には同じ分子量のバンドが 存在した。

C 6 S-PG の血清, 歯肉, GCF, の泳動パターンは C 4 S-PGのそれと類似していた（図 2 )。 


\section{考察}

歯肉溝滲出液は歯肉溝上皮や接合上皮を通じて組織 から歯肉溝に滲出するが, 炎症時に増量することから 炎症の一指標として臨床で用いられている。滲出液に は組織液, 血清成分, 細菌由来成分, 組織代謝成分が 含まれておりその比率は 1）歯肉縁下細菌の量と構成 比 2）歯肉結合組織の代謝回転比 3）上皮，基底膜， 結合組織の透過性 4）歯周組織の炎症の程度によって 変化する ${ }^{10)}$ 。

結合組織の一成分である GAG-PG が滲出液に含ま れることを最初に報告したのは Embry ら ${ }^{11,12) て ゙ あ る 。 ~}$ 彼等は人の健康な歯肉溝滲出液にはヒアルロン酸が含 まれ, 炎症時にはこれが増量するとともに硫酸化 GAG であるデルマタン硫酸, コンドロイチン硫酸を 検知した。

その後, 梶川 ${ }^{13)}$ はイヌの実験的歯肉炎をモデルにし て健常時にはヒアルロン酸と微量のヘパラン硫酸が, また急性炎症時には健常時には検知できなかった CS が認められたことを報告した。さらに，七トの実験的 歯肉炎ではヒアルロン酸は増量するが CS は存在しな いこと ${ }^{14)}$, 歯周外科処置後やクロールヘキシジン洗浄 後の滲出液では, 処置前にあった硫酸化 $\mathrm{GAG}$ が消失 した ${ }^{22)}$ 等の報告は, 歯肉溝滲出液に存在する CS を中 心とする硫酸化 $\mathrm{GAG}$ は歯周炎時の滲出液に特有のも のといえる。すなわち, ヒアルロン酸は深部組織に破 壊のない歯肉炎時に増量し, 硫酸化 GAG は歯周炎の 際に認められることから, CS は深部歯周組織の代 謝, 破壊産物と考えられる。

一方, 深部歯周組織, とりわけ歯槽骨 GAG の大部

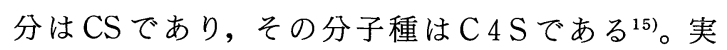
際, 骨代謝の著しい時期の歯肉溝滲出液には, 有意に C 4 S が増量する ${ }^{16,17 \text { ? }}$

現在までに行われた研究の結果は, C 4 S が歯槽骨 破壊の有力なマーカーとなる可能性を示しているとい える。しかしいずれの報告も直接証明ではなく, 状況 証拠の或を出ていない。とくに問題となる点は歯肉溝 滲出液成分に多大の影響を与える歯肉に, C 4 S-PG が証明されていることであろう18,19)。

本研究の結果は歯肉溝滲出液には歯周組織に由来す るものも存在することを分子量レベルで証明した。

すなわち, GCF の泳動膜にみれられる C 4 S-PG は, $55 \mathrm{kDa}$ に明瞭なバンド, 33-55 kDaに 5-6本の
細いバンド,さらに $20 \mathrm{kDa}$ 付近に明瞭な細いバンド が分布していた。そのうちの 33-55 kDa の間に検出 されたバンドと $20 \mathrm{kDa}$ 付近のバンドは, 血清には存 在しないものである。歯肉の CS-PGの分子量は 21-25 kDa という報告5)から考元ると, 本研究の 20 $\mathrm{kDa}$ 付近に検出された C $4 \mathrm{~S}-\mathrm{PG}$ がほぼそれに一致す る。33-55 kDa の間に見られる数本のバンドについて は，歯肉のそれと同一のものでない。従ってそのうち の一部のバンドは歯肉由来であるが, 他のバンドは血 清以外のもの, すなわち他の歯周組織に由来すると考 えるのが妥当であろう。

本田らはイヌの歯槽骨から $\mathrm{CsCl}$ 沈降平衡遠心後高 速液体クロマトグラフィ法を用いて PGを抽出し, SDS-PAGE によりPGの分子量を検討した結果，70 $\mathrm{kDa}$ と $76 \mathrm{kDa}$ にそれぞれ明瞭なバンドを認めた ${ }^{15)} 。$ 本研究の GCF にはそれに類似したバンドの検出は不 可能であった。しかし，歯槽骨破壊の活発な時期でな い健康な歯周組織の GCF であるため, 当然のことと 思われる。なお, 今回のイヌ血清の CS-PG の泳動パ ターンはおおむね桖清のものに近似してい た20,21)。C 6 S-PG の泳動像は C 4 S-PG と近似して いた。歯肉に $\mathrm{C} 6 \mathrm{~S}$ の検出が不可能であることが報告 されているが22,23), 近年免疫組織化学的手法によって その存在が証明された ${ }^{18,19)}$ 。しかし, 組織内分布, 染 色性は C $4 \mathrm{~S}$ に比較して劣り, 少量であることを伺わ せる。本研究においても C 6 S-PG は C 4 S-PG に比 較して染色度が低い傾向にあった。最近 HPLCの手 法を用いた分析でC 4 S と C 6 S はほぼ同量サルの歯 肉に存在することが報告されたが24), 動物種, 手法の 違いによるものと思われる。

一方，歯肉縁下歯石は成長過程で GCF の影響を強 く受けるものと考えられる。したがって縁下歯石の GAG 成分は $\mathrm{GCF}-\mathrm{GAG}$ を考察する有力な資料になり うるものと思われる。ヒトの歯肉縁下歯石からはヒア ルロン酸, CS, デルマタン硫酸が同定されたが, HPLCによるCS 分析では, その殆どはC $4 \mathrm{~S} て ゙$, C $6 \mathrm{~S}$ は痕跡のレベルであった ${ }^{25)}$ 。歯肉緑下歯石は成 長過程で主として GCF の有機成分を取込むものと思 われるが，なぜ C $6 \mathrm{~S}$ が検出されないかは不明であ る。しかし, ELISA 法による GCF の CS-PG の測定 では C 4 S に比してやや低いレベル程度の C 6 S-PG の存在が報告されていることを考慮に入れると, 免疫 学的手法と生化学的手法の差に基づくものと思われ る。 
本研究は GCF に C 4 S-PG, C 6 S-PG が存在する ことを分子量レベルで明らかにし，それと類似するも のが血清と歯肉に存在することから, GCF の CS-PG の由来は血清のみならず歯肉も含まれることを示唆し た。同一個体の GCF，歯肉，血清を同一方法で検討 した本研究の結果は, 比較する際の条件を満たしたも のである。対象動物, 手法の違いが比較を困難にする ことが多く, 今後は同一動物による手法の違いの差を 検討すること,さらに GCF 中の CS-PG の主供給源 とされている歯槽骨を本研究と同様の方法で検討する 必要があろう。

\section{結 論}

歯肉溝滲出液中の CS-PG (C 4 S-PG, C 6 S-PG) の主要バンドのプロフィールは血清のそれと類似して いたが, 血清には認められないが歯肉には認められる バンドが存在した。

このことは, GCF の CS-PGの由来組織として, 歯肉も含まれることを示したものである。

尚, 本研究は平成 5 年度文部省科学研究費 (一般 $C$ 萌, 課題番号 04807137）の補助により行われたことを付記し て感謝する。

\section{文献}

1）梶川欽一郎：結合組織，第一版，金原出版. 東京, 1984, 327.

2) Mayar, K. : Biochemistry and biology of mucopolysaccharides. Am. J. Med., 47 : 664-671, 1969.

3) Comper, W.D. and Laurent, T.C. : Physiological function of connective tissue polysaccharides. Physiol. Revy., 58:225-317, 1987.

4) Modis, L.: The molecular structure of the interfibellar matrix in connective tissue. Acta Biol. Acad. Sch. Hung., 29 : 197-226, 1978.

5) Bartold, P.M. : Proteoglycans of the periodontium: Structure, role and function. J. Periodont. Res., $22: 431-444,1987$.

6) Shibutani, T., Nishino, W., Shiraki, M. and Iwayama, Y., : ELISA detection of glycosaminoglycan (GAG) - linked proteoglycans in gingival crevicular fluid. J. Periodont. Res., 28:17-20, 1993.

7) Sobue, M., Takeuchi, J., Yoshida, K., Akao, S., Fukatu, T., Nagasaka, T. and Nakashima, N. :
Isolation and Characterization of Proteoglycans from Human Nonepithelial Tumors. Can. Res., 47:160-168, 1987.

8) Laemmli, U.K. : Cleavage of Structural proteins during the assembly of the head of bacteriophage T 4. Nature., 227:680-685, 1970.

9) Sobue, M., Nakashima, N., Fukatsu, T., Nagasaka, T., Fukata, S., Oiwa, N., Nara, Y., Ogura, T., Katoh, T. and Takeuchi, J. : Production and immunohistochemical characterization of monoclonal antibody raised to proteoglycan purified from a human york sac tumor. Histochem. J., $21: 455-459,1988$.

10) Curtis, M.A., Gillet, I.R., Griffiths, G.S., Maiden, M.F.J., Sterne, J.A.C., Wilson, D.T., Witon, J.M. A. and Jonson, N.W. : Detection of high-risk groups and individuals for periodontal diseases: Laboratory markers from analysis of gigival crevicular fluid. J. Clin. Periodontol., $16: 1-11$, 1989.

11) Embery, G., Oliver, W.M., Stanbury, J.B. and Purvis, J.A.: The electrophoretic detection of acidic glycosaminoglycans in human gingival sulcus fluid. Archs Oral Biol., 27 : 177-179, 1982.

12) Last, K.S., Stanbury, J.B. and Embery, G. : Glycosaminoglycans in human gingival crevicular fluid as indicators of active periodontal disease. Archs Oral Biol., $30: 275-281$, 1985.

13）梶川 潔：イヌの実験的歯周炎における歯肉溝滲出 液グリコサミノグリカンについて．日歯周誌., 28 : 500-515, 1986.

14）梶川 潔, 永橋理宏, 水野 清, 白木雅文, 岩山幸 雄 : 七トの実験的歯肉炎における歯肉溝滲出液中の グリコサミノグリカンについて．日歯周誌., 29 ： 844-852, 1987.

15）本田準虎, 吉村昌敏, 森本淳史, 小出修身, 白木雅 文, 岩山幸雄 : イヌ歯槽骨のプロテオグリカン. 日 歯周誌., $33: 897-906,1987$.

16) Last, K.S., Donkin, C. and Embery, G. Glycosaminoglycans in human gingival crevicular fluid during orthodontic movement. Archs Oral Biol., 33 : 907-912, 1988.

17) Last, K.S., Cawood, J.I., Howell, R.A and Embery, G. : Monitoring of Tübingen endosseous dental implants by glycosaminoglycans analysis of gingival crevicular fluid. Int J Oral Maxillofac Implants., $6: 42-49,1991$.

18) Sibutani, T., Murahashi, Y. and Iwayama, Y.': Immunohistochemical localization of chondroitin sulfate and dermatan sulfate proteoglycan in human gingival connective tissue. J. Periodont, Res., 24:310-313, 1989.

19）村橋慶宣：実験的歯周炎組織におけるコンドロイチ ン硫酸プロテオグリカンの免疫組織化学的局在性. 日歯周誌., $33: 35-55,1991$. 
20) Savolainen, H. : A sensitive method for the analysis of urinary proteoglycans. Biochem. Int., 28 : 475-479, 1992.

21) Imanari, T., Shinbo, A., Ochiai, H., Ikei, T., Koshiishi, I. and Toyoda, H. : Study on proteoglycans having low-sulfated chondroitin 4-sulfate in human urine and serum. J. pharmacobio-Dyn., 15:231-237, 1992.

22) Hiramatsu, M., Abe, I. and Minami, N. : Acid mucopolysaccharides in porcine gingiva. J. Periodont. Res., 13 : 224-231, 1978.

23) Sakamoto, N., Okamoto, H. Okuda, K. : Qualita- tive and quantitative analyses of bovine gingival glycosaminoglycans. Archs Oral Biol., 23 : 983987, 1978.

24) Okazaki, J., Kamada, A., Gonra, Y. and Skaki, T. : Analysis of chondrotin sulfate isomers in the periodontium of the monkey using high-performance liquid chromatography. J. Periodont. Res., 27 : 484-488, 1992.

25）本田準虎：ヒト歯肉縁上並びに縁下歯石のグリコサ ミノグリカンの分離とその特性. 日歯周誌., 34 : 620-632, 1992.

\section{連絡先：}

朝日大学歯周病学講座

干 501-02 岐阜県本巣群穂積町穂積 1851 